\title{
ÖĞRETMEN ADAYLARININ EPISTEMOLOJIK İNANÇLARI: BİR KARMA YÖNTEM ÇALIŞMA
}

\author{
EPISTEMOLOGICAL BELIEFS OF PRESERVICE TEACHERS: A MIXED METHOD \\ STUDY
}

\author{
Sevgi KOÇ ${ }^{1}$ \\ Hasan Basri MEMDUHOĞLU²
}

\section{$\ddot{\mathbf{O} z}$}

$\mathrm{Bu}$ çalışmada öğretmen adayı üniversite öğrencilerinin epistemolojik inançlarının belirlenmesi amaçlanmıştır. Bu genel amaç doğrultusunda; öğrencilerin epistemolojik inançlarının nasıl olduğu, öğrencilerin epistemolojik inançları; sınıf düzeyi, cinsiyet, okumakta oldukları bölüm değişkenlerine göre, anlamlı bir farklılık gösterip göstermediği araştırılmıştır. Çalışma grubuna önce ölçek uygulanmıș ve çalıșma grubundan bir grup katılımcı ile yarı yapılandırılmış görüșme yapılmıștır. Araştırmanın çalışma grubu 2012-2013 eğitim-öğretim yılında Yüzüncü Yıl Üniversitesi Eğitim Fakültesi fen bilimleri alanlarından fen bilgisi öğretmenliği ile fizik öğretmenliği bölümlerinde öğrenim görmekte olan toplam 280 öğrenciden oluşmaktadır. Her iki bölümün tüm sınıflarında okuyan öğrenciler çalışmaya dâhil edilmiştir. Ancak fizik öğretmenliğinin birinci sınıfında öğrenci bulunmadığından bu sınıf çalışmaya dâhil edilmemiş̧ir. Araştırmanın verileri Schommer (1990) tarafından geliştirilen, Tüzün ve Topçu (2008) tarafından Türkçe’ ye uyarlanan "Epistemolojik İnançlar Ölçeği" kullanılarak toplanmıştır. Ayrıca 24 kişilik bir çalışma grubuyla bireysel görüşmeler yapılmıştır. Ölçekle elde edilen verilerin çözümlenmesinde betimsel analizler ve parametrik testler kullanılmıştır. Bireysel görüşmelerle elde edilen veriler içerik analiziyle çözümlenmiştir. Schommer (1990)' in modelinde, gelişmemiş ya da olgunlaşmamış epistemolojik inançlara sahip olan bireyler; bilginin basit, kesin/değiştirilemez olduğunu, öğrenmenin hemen gerçekleştiğini, öğrenme yeteneğinin doğuştan olduğunu ve sonradan geliştirilemeyeceğini; gelişmiş ya da olgunlaşmış epistemolojik inançlara sahip bireyler bilginin karmaşık olduğunu, değiştiğini, öğrenmenin zaman aldığını ve çaba gerektirdiğini düşünürler. Öğrencilerin üniversiteye, bilginin mutlak ve kesin kolay anlaşılır, birbiriyle ilişkisiz parçalardan oluşan bir yapıya sahip ve bir uzman (otorite) tarafindan oluşturulup öğrencilere aktarılan bir şey olduğuna inanarak geldikleri belirlenmiştir. Bu araştırmada, bölüm değişkenlerine, cinsiyete ve sinıflar arası düzeye göre incelendiğinde değişkenler arasında anlamlı farklılıklar bulunmamıştır. Sonuç olarak, öğretmen adaylarının epistemolojik inançlarının gelişmemiş/olgunlaşmamış olduğu, görüşlerinin bölüm, sınıf ve cinsiyet değişkenlerine göre değişmediği belirlenmiş̧ir. Üniversite öğrenimi süresince öğrencilerin epistemolojik inançlarında hiç bir değişikliğin olmadığı görülmektedir.

Anahtar Kelimeler: Epistemolojik inanç, öğretmen eğitimi, karma yöntem çalışma.

\begin{abstract}
In this research; determination of epistemological beliefs of preservice teachers was aimed. In accordance with this general purpose, epistemological beliefs of students and whether these beliefs differ meaningfully according to some variables like gender, class level and the department; the study was researched. First, the selected study group was scaled and then a semistructured interview was made with some participants from the study group. The study group of research consists of 280 students in total who studied science teaching and physics teaching in Faculty of Education in Yüzüncü Y1l University during 2012-2013 academic year. The students of every grade of both departments were involved in the research. But, as the physics teaching department doesn't have 1st grade students, this grade wasn't incorporated into the research. The data of the research was collected using "Epistemological Beliefs Scale" which was developed by Schommer (1990) and adapted to Turkish by Tüzün and Topçu (2008). Besides, individual interviews were made with a study group of 24 preservice teacher. Descriptive analysis and parametric tests were used for analyzing the data which was obtained with scale. The data obtained with individual interviews was analyzed with content analysis. In Schommer's (1990) model, individuals who have undeveloped or immature epistemological beliefs think that knowledge is simple, immature/unchangeable, learning take place immediately and learning ability is innate and can't be developed later while individuals who have developed or mature epistemological beliefs think that knowledge is complicated and changes, learning takes time and requires effort. Accordingly, it was determined that students come to university believing that knowledge is absolute and precise, lucid has a structure consisting of irrelevant components and that is something formed and transferred to students by an expert. When the research was examined according to department, gender and class level variables, meaningful differences weren't found between variables. As a result of the study, it was determined that epistemological beliefs of preservice teachers are undeveloped/immature and their ideas don't differ according to department, class and gender variables. It is seen that there isn't any change in students' epistemological beliefs during their university study period.
\end{abstract}

Keywords: Epistemological belief, teacher education, mixed method study.

\footnotetext{
${ }^{1}$ Arş.Gör., Yüzüncü Y1l Üniversitesi, Eğitim Fakültesi, OFMAE, sevgitoluk@ hotmail.com

2 Doç. Dr. Yüzüncü Y1l Üniversitesi, Eğitim Fakültesi, Eğitim Bilimleri, Eğitim Yönetimi, hasanmemduhoglu@ gmail.com
} 


\section{GİRIŞ}

Post Pozitivist paradigmanın ortaya çıkmasıyla bilginin kesinliği ve genellenebilirliği yön değiş̧tirmiş; birbiriyle ilintili, özne merkezli, bakış açısının yer aldığı, birey tarafından yorumlanan ve oluşturulan bilgiye dönüşmüştür. Bilim öğretiminde idealize edilen yapılandırmacı epistemoloji, bilimsel bilginin tartışma ve yorumlara açık pek çok farklı süreçten geçerek oluştuğuna inanan ögrenciler yetiştirilmesi gerektiğine işaret eder. $\mathrm{Bu}$ anlayışla öğrenen bireylerin, pozitivist inanca sahip olanlara göre bilgiyi daha uzun süre saklayabildiği ve daha yeni fikirler oluşturabildiği kabul edilmektedir (Buehl, 2003).

Bireylerin bilginin, bilmenin ve öğrenmenin doğasına ilişkin anlamaları epistemoloji olarak tanımlanmıştır (Hofer ve Pintrich, 1997). Kişisel epistemolojiyi dört farklı çerçevede ele alan ontolojik açıklamalar bulunmaktadır. Bunlar; gelişimsel modeller, inançlar, teoriler ve kaynaklardan oluşmaktadır. Genel olarak epistemolojik inançlar ve epistemolojik teoriler ile ilgili psikolojik çalışmaların başlangıcı William Perry tarafından 1970 'lerde Harvard Üniversitesi lisans öğrencilerinin yer aldığı boylamsal bir çalışmayla birlikte başlamıştır. Perry üniversite öğrencileri üzerinde yaptığı araştırmada, öğrencilerin öğrenimlerinin ilk y1lında büyük çoğunluğunun bilginin basit, değişmeyen bir olgu olarak her şeyi bilen bir otorite tarafından verildiğine inanırken, üniversitedeki öğrenim yaşamlarının son yılına doğru, bilginin karmaşı, deneye ve akıl yürütmeye dayalı bir olgu olduğuna inandıkları sonucunu elde etmiştir (Schommer-Aikins, 2004).

Epistemolojik inançları gelişkin bireylerin akademik başarılarının daha yüksek olduğu, daha etkili öğrenme alışkanlıklarına sahip oldukları, yeni karşılaştıkları bilgileri ne düzeyde kavradıklarını denetlemede daha başarılı oldukları da belirtilmektedir (Schommer, 1990). Epistemolojik inançlar bir öğretmenin öğretim yöntemi, sınıf yönetimi gibi boyutlarda vereceği kararları ve seçimleri de etkiler. Bu çalışmada ise inanç sistemi içinde önemli bir yere sahip olan ve etkili bir öğretmen değişkeni olduğu düşünülen bilimsel epistemolojik inançlar odak noktaya alınmıştır. Çünkü bu çalışma alanı hem eğitimcilerin profillerini belirlemek için kullanılabilecek ölçülebilir özellikler sunması (Brownlee, 2001) hem de kişinin öğrenme ve öğretme kavramlarını algılayışı üzerinde etkili bir değişken olması (Chan, 2003) nedeni ile öğretmen öğesini tanımlamada önem taşımaktadır. Bu boyutlarda sınıf içinde öğretmenleriyle sürekli etkileşim içinde olan öğrencilerin bilime ilişkin anlayışlarını doğrudan etkileyecektir. Bu nedenle bir öğretmenin sahip olduğu epistemolojik inancin öğrencilerinin sahip oldukları epistemolojik inancın yönünün belirlenmesinde oldukça etkili bir değişken olduğunu söylemek yanlış olmayacaktır. Araştırmalarda öğretmenlerin sahip oldukları bilimsel epistemolojik inançlar ile öğretimleri arasında bir ilişki olduğunu ortaya koymaktadır (Richardson, 1991; Akt: Bernardo, 2008). Özellikle MEB'in yapılandırmacı uygulamaları merkeze aldığı ülkemizde öğretmenlerin bu anlayışla uyumlu bir epistemolojik inanca sahip olup olmadıkları da ayrıca önem taşımaktadır.

Üniversite öğrenimi sürecinde, son sınıfa doğru öğrencilerin, bilginin mutlak ve kesin olamayacağına, yani duruma göre doğru ya da yanlış olabileceğine, birbiriyle ilişkili birçok parçadan oluşan karmaşık bir yapıya sahip olduğuna ve akıl yoluyla ya da deneysel kanıtlara dayanılarak birey tarafından oluşturulduğuna inandıkları saptanmıştır. Perry (1970), öğrencilerin bilginin ne olduğu ve nasıl edinildiğine ilişkin inançlarının onların bilme, öğrenme ve ders çalışma biçimleri üzerinde gözlemlenebilir farklılaşmalara neden olduğu sonucuna varmıştır. Schommer, bu yeni anlayışıyla 1988, 1990 yıllarında bir araştırma programı başlatmıştır. Bu araştırmalarla bilgi bilimsel inançlar, az ya da çok bağımsız bir inanç sistemi olarak yeniden kavramsallaştırılmıştır. Burada "sistem" kelimesinin kullanılmasının nedeni, dikkate alınması gereken farklı inançlar olmasıdır. "Az ya da çok bağımsız" ifadesi ise bireylerin inançlarının birbirleriyle kıyaslandığında aynı yetkinlik 
seviyesinde olmaması temel alınarak kullanılmıştır. Örneğin, bazı öğrenciler bilginin değişmez olduğuna inanabilir; fakat aynı zamanda bilginin oldukça karmaşık olduğuna da inanabilirler. İşte bu sebeple bilgi bilimsel inançların yapısı gereği ölçümü de tek boyutlu olmamalidir (Schommer, 1998).

Schommer (1990), epistemolojik inançları bilginin ve öğrenmenin doğasına ilişkin inançlar olarak tanımlamış ve epistemolojik inançlar sisteminin boyutlarını bilginin kesinliği, bilginin organizasyonu, bilginin kaynağı, öğrenmenin hızı ve öğrenmenin kontrolü şeklinde belirlemiştir. Bununla birlikte Schommer (1990), epistemolojik inanç boyutlarının eş zamanlı bir gelişim göstermek durumunda olmadığını vurgulayarak, bu boyutların birbirlerine göre az ya da çok bağımsız olduklarını varsaymıştır. Bu bağlamda gerçekleştirilen pek çok araştırma, Schommer (1990) in varsayımının desteklenmekte olduğunu göstermektedir (SchommerAikins, 1990, 1994; Schommer-Aikins ve Easter, 2006; Chan ve Elliott, 2002, 2004; Braten ve Stromso, 2005, 2006). Diğer taraftan, başta Perry (1970) olmak üzere, King ve Kitchener (1994), Baxter-Magolda (1992) ve Belenky ve arkadaşları (1986) gibi birçok araştırmacı da kişisel epistemolojiyi bilgi ve bilmenin doğasına ilişkin bilişsel gelişimle özdeş bir biçimde kavramsallaştırmışlardır. Bununla birlikte, söz konusu araştırmacılar bireylerin kişisel epistemolojilerinin yaş, eğitim düzeyi vb. özelliklerine göre ardışık bir gelişim göstereceğini de öne sürmüşlerdir.

Schommer (1990)' in modelinde, gelişmemiş ya da olgunlaşmamış epistemolojik inançlara sahip olan bireyler; bilginin basit, kesin/değiştirilemez olduğunu, öğrenmenin hemen gerçekleştiğini, öğrenme yeteneğinin doğuştan olduğunu ve sonradan geliştirilemeyeceğini düşünürlerken, gelişmiş ya da olgunlaşmış epistemolojik inançlara sahip bireyler bilginin karmaşık olduğunu, değiştiğini, öğrenmenin zaman aldığını ve çaba gerektirdiğini düşünürler. Öğrenme sürecinde öğrenme, düşünme, akıl yürütme ve kavrama gibi süreçlerle birlikte, akademik başarı, motivasyon ve problem çözme gibi eğitimsel açıdan öğrencilerin epistemolojik inançlarının çok boyutlu rollere sahip olduğu yönünde çalışmalar bulunmaktadır (King ve Kitchener, 1994; Schommer-Aikins vd., 2000; Hofer, 2000; Mason ve Boscolo, 2004; Schommer-Aikins ve Easter, 2006). Bunlarla birlikte, öğrencilerin epistemolojik inançları arasında öğrenim gördükleri alanlara (Hofer, 2000), cinsiyetlerine (Baxter-Magolda, 1992; Cano, 2005) ve sinıf düzeylerine (Cano, 2005) yönelik olarak farklılıkların elde edildiği araştırmalarla, epistemolojik inançların hem genel (Schommer, 1990, 1994; Schommer vd., 2000) hem de alan odaklı (Buehl, 2003) bakış açılarıyla incelendiği araştırmalardan elde edilen bulgular dikkate alındığında, öğretme-öğrenme süreçlerinin planlanması ve gerçekleştirilmesinde epistemolojik inançlar konusunun önemli bir konumda yer aldığı görülmektedir.

Bir eğitim programının etkililiğinde öğretmen ve öğrenci arasındaki etkileşimin programın belirlenen hedeflere ulaşması açısından önemi düşünüldüğünde (Demirel, 2004), söz konusu etkileşimin sağlıklı bir biçimde gerçekleşmesi, dolayısıyla da programın hedeflerine ulaşabilmesi açısından öğrencilerin epistemolojik inançlarının dikkate alınması gereken önemli değişkenlerden biri olduğu söylenebilir. Bir bilim alanında öğrenimine yeni başlayan öğrencilerle (1. sınıflar), öğrenimlerinde belirli bir düzeyde bulunan öğrencilerin (4. sınıflar) genel epistemolojik inançlarına yönelik olarak elde edilecek bulguların öğrencilerin epistemolojik inançlarını gelişimsel yönlerini de içermekte oldukları söylenebilir. Dolayısıyla, araştırmadan elde edilecek bulgular, araştırmanın örneklemi kapsamındaki alanlara ilişkin olarak gerçekleştirilecek olan program geliştirme çalışmalarına, epistemolojik inançlara ilişkin söz konusu gelişimsel yönlerinde dikkate alınmasını sağlayarak önemli katkılar sağlayabilecektir.

Nitekim farklı eğitim programlarının doğasının gerektirdiği varsayımıyla ya da inancıyla herhangi bir derse ilişkin olarak gerçekleştirilen öğretimsel uygulamaların, 
öğrencilerin epistemolojik inançlarındaki gelişimi olumlu ya da olumsuz biçimde etkileyebileceği yönünde bazı kanıtlar mevcuttur (Lloyd, 2003). Örneğin, fizikte kuram haline gelmiş bilgilerin artık tartışılmayacağına ilişkin epistemolojik inanca sahip olan bir öğretim elemanının ya da öğretmenin öğretimsel uygulamaları, öğrencilerin eleştirel düşünme, yaratıcı düşünme gibi düşünme süreçlerinin gelişimini sınırlandırabilir. Bunlarla birlikte, literatürde öğrencilerin genel epistemolojik inançlarının öğrenme stratejilerini, çalışma stratejilerini, motivasyon stillerini doğrudan ya da dolaylı olarak yordamakta olduğuna ilişkin bulgular da mevcuttur (Cavallo vd., 2003; Buehl ve Alexander, 2001; Duell ve Schommer-Aikins, 2001). $\mathrm{Bu}$ yönüyle çalışmanın, eğitim öğretim süreçlerinin öğrenen odaklı bir biçimde gerçekleştirilebilmesine yönelik çalışmalara dolaylı bir biçimde katkı sağlayacağı da söylenebilir.

Epistemolojik inançları gelişmiş öğrenciyi yetiştirecek olan öğretmen adaylarının bu inanca sahip olup olmadıklarının belirlenmesi de bu noktada önem taşımaktadır. Epistemolojik inançlar bir öğretmenin öğretim yöntemi, sınıf yönetimi gibi boyutlarda vereceği kararları ve seçimleri de etkiler. Bu çalışmada ise inanç sistemi içinde önemli bir yere sahip olan ve etkili bir öğretimde önemli bir değişken olduğu düşünülen geleceğin öğretmenleri öğretmen adaylarının bilimsel epistemolojik inançları odak noktası olarak düşünülmüştür. $\mathrm{Bu}$ bağlamda öğretmen adaylarının bilimsel epistemolojik inançlarının ne düzeyde olduğu çeşitli değişkenler açısından incelenmiştir. Ayrıca yarı yapılandırılmış görüşme mülakatlarıyla öğretmen adaylarının epistemolojik inançları derinlemesine araştırılmaya çalışılmıştır.

\section{Araştırmanın Amacı}

$\mathrm{Bu}$ çalışmanın amac1, öğretmen adayı üniversite öğrencilerinin epistemolojik inançlarının belirlenmesi ve bu inançlarının sınıf düzeyi, cinsiyet, okumakta oldukları bölüm değişkenlerine göre farklılık gösterip göstermediğini belirlemektir.

\section{YÖNTEM}

\section{Araştırmanın Modeli}

$\mathrm{Bu}$ araştırmada daha güvenilir sonuçlar elde etmek için nitel ve nicel yaklaşımları kapsayan karma araştırma yöntemi kullanılmıştır. Araştırmanın desenlenmesinde sıralı açıklayıcı desen kullanılmıştır. Bu desenlemede nicel ağırlıklı yapılan çalışma nitel verilerle desteklenmektedir (Creswell vd., 2003). Başka bir ifadeyle nitel çalışma verileri, nicel verileri yorumlamada desteklemek amacı ile tamamlayıcı nitelik taşımaktadır. Bu kapsamda seçilen çalışma grubuna önce ölçek uygulanmış, çalışma grubundan bir grup katılımcı ile yarı yapılandırılmış görüşme yapıllmıştır.

\section{Çalışma Grubu}

Araştırma fen bilimleri alanlarında öğrenim görmekte olan öğretmen adayı öğrenciler üzerinde uygulanmıştır. Bu alandaki öğrenciler, örneklemede kolay ulaşılabilirlik ölçütüyle tercih edilmiştir. Araştırmanın çalışma grubu 2012-2013 eğitim-öğretim yılında Yüzüncü Yı1 Üniversitesi Eğitim Fakültesi fen bilgisi öğretmenliği ile fizik öğretmenliği bölümlerinde öğrenim görmekte olan toplam 280 öğrenciden oluşmaktadır. Her iki bölümün tüm sınıflarında okuyan öğrenciler çalışmaya dâhil edilmiştir. Ancak fizik öğretmenliğinin birinci sınıfında öğrenci bulunmadığından bu sınıf çalışmaya dâhil edilememiştir. Buna göre fen bilgisi öğretmenliğinde birinci sınıftan dördüncü sınıfa, fizik öğretmenliğinde ikinci sınıftan beşinci sınıfa kadar tüm sınıflar çalışmaya dâhil edilmiştir. Bölümlerde 1.sınıftan 5. sınıfa kadar tüm sınıfların araştırmaya dâhil edilmesiyle, üniversite eğitiminin öğrencilerin 
epistemolojik inançlarında yarattığı değiş̧imin belirlenmesi amaçlanmıştır. Çalışma grubunda yer alan öğrencilere ilişkin bazı bilgiler Tablo 1' de verilmiştir.

Tablo 1. Araştırmanın çalışma grubunu oluşturan öğrencilerin kişisel özellikleri

\begin{tabular}{llcc}
\hline \multirow{2}{*}{ Değişken } & Düzey & $\mathrm{N}$ & $\%$ \\
\hline \multirow{2}{*}{ Bölüm } & Fen Bilgisi Öğr. & 205 & 73 \\
& Fizik Öğr. & 75 & 27 \\
\hline \multirow{2}{*}{ Cinsiyet } & Kadın & 138 & 49 \\
& Erkek & 142 & 51 \\
\hline \multirow{5}{*}{ Sinıf } & 1.Sınıf & 26 & 9 \\
& 2.Sınıf & 70 & 25 \\
& 3.Sinıf & 82 & 29 \\
& 4.Sinıf & 77 & 28 \\
& 5.Sinıf & 24 & 9 \\
\hline
\end{tabular}

Tablo 1' de görüldüğü gibi öğrencilerin çoğunluğu fen bilgisi öğretmenliğinde öğrenim görmektedir. Çalışmaya katılan öğrenciler arasında kadın erkek oranı birbirine yakındır. Birinci ve beşinci sınıfta okuyan öğrenci sayıları diğer sınıflara göre daha düşüktür. Bunun nedeni, fen bilgisi bölümünde beşinci sınıf olmaması, fizik öğretmenliği bölümünde de birinci sinıfta öğrenci bulunmamasıdır.

Çalışmada ayrıca çalışma grubunda yer alan 24 kişilik bir öğrenci grubuyla görüşmeler yapılmıştır. Bu görüşmelere katılan öğrencilerden 16'sı erkek, 8' i ise kadındır. Görüşme yapılacak öğrenciler belirlenirken, araştırmaya katılan toplam sekiz sınıfın her birinden rastgele üçer öğrenci seçilerek çalışma grubu oluşturulmuştur.

\section{Veri Toplama Araçları}

Araştırmada iki tür veri toplama aracı kullanılmıştır.

Nicel Veri Toplama Aracı: Nicel veriler için Schommer (1990) tarafından geliştirilen ve Tüzün ve Topçu (2008) tarafindan Türkçe' ye uyarlanan "Epistemolojik İnanç Ölçeği" kullanılmıştır. Epistemolojik İnanç Ölçeği, öğrencilerin epistemolojik inanç ifadelerine katılım düzeylerini belirlemeye yönelik beşli Likert türü bir derecelendirme ölçeğidir. Schommer (1990), kişisel epistemolojiyi birbirlerinden az ya da çok bağımsız boyutlardan oluşan bir inançlar sistemi olarak ele almıştır. Bu doğrultuda Schommer'in (1990) ölçeği, bilginin yapısı (bilgi izole parçalardan oluşur inanc1 ile bilgi entegre kavramlar şeklindedir inancı arasında yer alan bir dağılım), bilginin sabitliği (bilgi değişmezdir ve sürekli bir biçimde değişmektedir inançları arasında yer alan bir dağılım), öğrenmenin hızı (öğrenme ya hızlı bir biçimde gerçekleşir ya da hiçbir biçimde gerçekleşmez inancıyla öğrenme derecelidir inancı arasında yer alan bir dağılım) ve öğrenme yeteneği (öğrenme yeteneği doğuştan belirlenir ile ögrenme yeteneği zamanla ve yaşantılarla gelişstirilebilir inançları arasında yer alan bir dağılım) şeklinde belirlediği beş boyuttan oluşmaktadır. Çalışmada kullanılan ölçek; öğrenme hızı, basit bilgi, kesin bilgi ve doğuştan öğrenme boyutlarında toplam 63 maddeden oluşmaktadır. Tüzün ve Topçu (2008) tarafindan yapılan uyarlama çalışması sonuçlarına göre ,25 ile ,60; Schommer' in (1990) çalışmasında ise alpha güvenirlik katsayıs1 ,51 ile ,78 arasında bulunmuştur. Topçu (2011) çalışmasında alpha güvenirlik katsayısı ,35 ile ,60 arasında bulunmuştur. Bu çalışmada ölçeğin güvenirliği için tekrar hesaplanan Cronbach alpha güvenirlik katsayısı ,62 olarak bulunmuştur. Schommer (1990), kişisel epistemolojiyi birbirlerinden az ya da çok bağımsız boyutlardan oluşan bir inançlar sistemi olarak ele almıştır. Bu doğrultuda Schommer (1990)' in ölçeği, bilginin yapısı (bilgi izole parçalardan 
oluşur inancıyla bilgi entegre kavramlar şeklindedir inancı arasında yer alan bir dağılım), bilginin sabitliği (bilgi değişmezdir ve sürekli bir biçimde değişmektedir inançları arasında yer alan bir dağglım), öğrenmenin hızı (öğrenme ya hızlı bir biçimde gerçekleşir ya da hiçbir biçimde gerçekleşmez inancıyla öğrenme derecelidir inancı arasında yer alan bir dağglım) ve öğrenme yeteneği (öğrenme yeteneği doğuştan belirlenir ile öğrenme yeteneği zamanla ve yaşantılarla geliştirilebilir inançları arasında yer alan bir dağılım) ş̧eklinde belirlediği beş boyuttan oluşmaktadır. Ölçekten alınan en düşük puan 63, en yüksek puan 315' tir. Ortalamalara ilişkin aralık belirlenirken, öğrenmenin doğasına ilişkin 16 madde, bilginin basitliğine ilişkin, 28 madde, öğrenme hızına ilişkin 13 madde, bilginin kesinliğine ilişkin 6 madde olarak toplam 63 maddeden oluşmuş ölçeğin boyutlarının ortalamaları madde sayılarına bölünerek hesaplanmıştır. Ayrıca 5' li likert tipi olan ölçeğin ranj aralıkları belirlenirken, 0- 0.80 aralığ 1 çok düşük düzeyde katılımı, 0.80 - 1.60 aralığ 1 düşük düzeyde katılımı, 1.60- 2.40 aralığı orta düzeyde katılımı, 2.40-3.20 aralığı yüksek düzeyde katılımı, 3.20- 4.00 aralığ çok yüksek düzeyde katılımı belirtmektedir.

Nitel Veri Toplama Aracı: Nitel veriler için yarı yapılandırılmış görüşme formu kullanılmıştır. Bu formda uzman görüşüne göre ölçek boyutları dikkate alınarak ve ölçekteki ifadelerden yararlanılarak öğrenmenin doğasına ilişkin boyutta "öğrenme yeteneği doğuştan gelen bir kabiliyettir" ifadesi hakkında ne düşünüyorsunuz?, bilginin basitliğine ilişkin boyutta "yazarın amacını bilmeden, onun kitabının vermek istediği fikri asla bilemezsin" ifadesi hakkında ne düşünüyorsunuz?, öğrenmenin hızına ilişkin boyutta, "öğrenmek, bilginin yavaşça üst üste inşa edildiği bir işlemdir", ifadesi hakkında ne düşünüyorsunuz?, bilginin kesinliği boyutunda ise "kesin olan tek şey, hiçbir şeyin kesin olmadığıdır" ifadesi hakkında ne düşünüyorsunuz?, gibi sorular sorularak oluşturulmuştur.

\section{Verilerin Analizi}

Nicel verilerin çözümlenmesinde betimsel istatistikler (yüzde, frekans, aritmetik ortalama, standart sapma) ve verilerin normal dağılım göstermesi nedeniyle ( $t$ testi ve tek yönlü varyans analizi/ANOVA) uygulanmıştır. Araştırmada faktörlerden elde edilen puanlar yorumlanırken düşük puan gelişmiş/olgunlaşmış epistemolojik inanç, yüksek puan ise gelişmemiş/olgunlaşmamış epistemolojik inanç olarak açıklanmıştır (Deryakulu, 2004; Schommer-Aikins ve ark., 2000).

Yarı yapılandırılmış görüşme formu kullanılarak yapılan görüşmelerden elde edilen nitel veriler, içerik analizi ile çözümlenmiş ve 4 boyut altında kategorilendirilerek temalara göre betimlenmiştir. Ayrıca öğrencilerin görüşleri doğrudan alıntılarla desteklenmiştir. Doğrudan alıntılama yapılırken öğrenciler kodlanarak görüşleri verilmiştir. Kodlamada öğrencilerin bölüm, sınıf ve cinsiyet değişsenlerini gösterecek harfler kullanılmış ve her öğrenciye bir numara verilmiştir. Fen Bilgisi öğrencileri "FN", fizik bölümü öğrencileri "FZ" harfleriyle kodlanmıştır. Örneğin Fizik bölümü 3.sınıftaki bir erkek öğrencinin görüşü belirtilirken "FZ3E4" şeklinde kodlanarak verilmiştir. Buna göre Fen Bilgisi öğrencileri "FN", fizik bölümü öğrencileri "FZ" şeklinde kodlanırken, sonra sınıf numaraları ile birlikte, kadın katılımcılar "K", erkek katılımcılar "E" harfleriyle kodlanmış, aynı zamanda her öğrenciye bir numara verilmiştir. Örneğin Fizik bölümü 3.sınıf öğrencisi ile görüşme yapılan bir erkek öğrencinin görüşü belirtilirken "FZ3E4" şeklinde kodlanarak verilmiştir.

\section{BULGULAR VE YORUM}

Araştırma bulguları; "öğrencilerin epistemolojik inançlarına ilişkin bulgular ve öğrencilerin epistemolojik inançlarının kişisel değişkenlerle ilişkisine ilişkin bulgular" başlıkları altında sunulmuştur. 


\section{Öğrencilerin Epistemolojik İnançlarına İlişskin Bulgular}

Araştırmaya katılan öğrencilerin bilimsel epistemolojik inançlarını yansıtan görüşlerinin ölçeğin toplamında ve boyutlarında aritmetik ortalama ve standart sapma değerleri Tablo 2' de verilmiştir.

Tablo 2. Ölçeğin boyutlarına göre öğrencilerin epistemolojik inançlarına ilişkin bulgular

\begin{tabular}{lcc}
\hline Faktörler & $\bar{X}$ & ss \\
\hline Öğrenmenin doğası (öğrenme doğuştandır) & $2.50 / 40.03$ & 8.37 \\
Bilginin basitliği & $2.93 / 82.09$ & 8.34 \\
Öğrenme hızı & $2.53 / 32.95$ & 6.26 \\
Bilginin kesinliği & $2.75 / 16.55$ & 3.79 \\
\hline Toplam & $2.72 / 171.63$ & 17.79 \\
\hline
\end{tabular}

Tablo 2' de görüldüğü gibi araştırmaya katılan öğrenciler ölçeğin ilk boyutunda "öğrenmenin doğuştan olduğu" görüşüne orta düzeyin biraz üstünde katıllım göstermişlerdir $(X=2.50)$. Başka bir ifadeyle, öğrenmenin doğasına (öğrenme yeteneğinin doğuştan olduğuna) ilişkin öğrencilerin bilimsel epistemolojik inançlarının orta düzeyin biraz üstünde olduğu görülmektedir. $\mathrm{Bu}$ araştırmada öğrencilerin epistemolojik inançlarıyla ilgili daha derinlemesine veri toplamak için yapılan nitel görüşmelerde, öğrenmenin doğası boyutunda öğrencilerin çoğunluğu, öğrenme yeteneğinin doğuştan olduğunu düşünürken; bir kısm1, öğrenmenin doğuştan olmadığını ifade etmiş ve birkaç kişi ise öğrenmenin hem doğuştan, hem de sonradan olabileceği şeklinde görüş belirtmişlerdir. Öğrenme yeteneğinin doğuştan olduğunu savunan öğrenciler, bu konuda genelde öğrenmenin doğuştan olduğunu, bilgi ve duyguların insanda doğuştan var olduğunu, yaşantı sürecinde bu bilgilerle karşılaşıldığında bu bilgilerin tazelendiğini, öğrenmenin sonradan değiştirilmesinin zor olduğunu, herkesin öğrenme yeteneğinin farklı olduğunu düşünmektedirler. Öğrenme yeteneğinin doğuştan olmadığını düşünenler bu konuda şu görüşleri belirtmişlerdir: "öğrenme doğuştan değil, sonradan çalışılarak kazanılır; öğrenme kişinin öğreneceği şeye ilgi duymasıyla ve kendisini nasıl geliştirdiği ile ilgilidir". Öğrenmenin doğuştan kazanılan bir yetenek olduğuna ya da sonradan kazanıldığına inanan öğrencilerin belirttiği görüşlerden bazıları aşağıdaki gibidir:

- "Öğrenme yeteneği doğuştan gelen bir kabiliyettir. Bir çocuk doğduktan sonra sürekli arayış içerisinde eliyle, ağzlyla aslında var olan bir şeyleri ve bilgileri sürekli keşfetmektedir. Örneğin bir çocuk yeni doğan kardeşini çok kuskanır, kıskançlık sonradan $m i$ ögretilmiştir ki kıskansın. Tamamen doğumdan itibaren içine yerleştirilmiş bir ögrenme modelidir (FN4E12)".

- "Insan beyninde her şey kayıtlıdır. Sadece görüldüğ̈̈nde üzerindeki toz alınır ve taze bilgi olarak kullanilır (FN3E7)".

- "Öğrenme yeteneği doğuştan gelen bir yetenektir. Örneğin, hoca modüler aritmetik konusunu anlatır, sınıftaki öğrenciler konuyla ilk kez karşılaşmaktadır. Soru çözümüne geçildiği vakit bazıları hiç bir soruyu çözemez, fakat bütün soruları çözebilenler de vardır. Herkes aynı hocadan ders almıştır, herkese aynı sorular sorulur, fakat notlar farklı farklıdır. Bu örnekten hareketle ögrenebilmek bir yetenektir, doğuştan sinırları verilmiştir. Hizlı ögrenebilmek (kapasitesi dâhilinde) kendi elindedir (FZ5E24)".

- "Öğrenme yetenek değil, çalışma ürünüdür (FZ2E14)".

- "Öğrenme sonradan ögrenilir ve geliştirilir (FZ4E21)".

- "Öğrenme yeteneği aile ve çevresinden etkilenerek, görerek, uygulayarak başarılar elde edilebilir. Bunun da çalışmaktan geçtiği aşikârdır (FN1E3)". 
- "Bir insanın doğuştan bazı şeyleri vardır; bunları zamanla değiştiremez. Yani kapasitesinin üstüne kesinlikle çıkamaz. Kendisini biraz geliştirebilir ama kesinlikle her şeyi ögrenemez (FZ5E22)".

- "Ö̆̆renme yeteneği kalttsal olmayıp bireyin kendisini nasıl geliştirdiği ve bu bilginin bireyde nasıl davranışsal değişikliğe sebep olduğundan kaynaklanır (FZ5E23)".

- "Bu konuda kararsızım. Bazı insanlar bir kere bir şeyi okuduğunda anlarken bazıları iki üç kere okuyarak kavrayabiliyor. Ama okuyarak bunun geliştirilebileceğine de inaniyorum (FN3K9)".

- "Bence öğrenme hem doğuştandır hem de değildir. Öğrenmenin ne ile ilgili olduğuna bağlıdır. Fıtratta olanlar doğuştan getirilir ama ilmi bilgiler sonradan da kazanılabilir (FZ3E16)".

- "Yetenek doğuştan gelir. Öğrenme çalışılarak kazanılır ve öğrenme yeteneği geliştirilir (FZ4E19)".

Tablo 2 incelendiğinde araştırmaya katılan öğrencilerin ölçeğin ikinci boyutu olan bilginin basitliğine ilişkin bilimsel epistemolojik inançlarının $(X=2.93)$ puan ortalamaları yüksek düzeyde çıkmıştır. Bilginin basitliği boyutuna ilişkin değerlendirme yapan katılımcı öğrenciler bir yazarın kitabını okurken yazarın amacını bilmeye gerek olmadığını, kitabı okuduğumuzda kendi akıl ve mantığımızla kitabın bize anlatmak istediğini kolayca anlayabileceğimizi, kitabın içine girilirse yazarın amacının anlaşılacağını, kitabı detaylı bir şekilde incelediğimizde zaten yazarın amacının da bilineceği gibi görüşler paylaşmışlardır. $\mathrm{Bu}$ fikirlerin yanı sıra katılımcı öğrencilerin bir kısmı da bir yazarın kitabını okurken yazarın amacını bilmek gerektiğini düşünmektedirler. Bu boyutta öğrencilerin belirttiği görüşlerden bazıları aşağıdaki gibidir:

- "Bir yazarin vermek istediği düşünceyi bilmek daha sabitleyici fikre bağll olarak okumaktır, öğrenmektir. Bir örnek ile değerlendirirsek: Bir gün bir hoca sınıfta bir söz söylemiş ve bu konu hakkında ögrencilerinden yorumlarını istemiş ve yorumlara baktığında her bir yorumun farklı bir şeyler anlattı̆̆ını görmüş ve kendi kendine ben neler söylemişim de haberim yokmuş'. Yazarl da bir hoca gibi düşünebiliriz, yani yazarın düşüncelerini bilmezsek belki yazarın değil de kendi özgün düşüncelerimizi yorumlayabiliriz (FN4E11)".

- "Yazar bir bilgiyi aktarmak istediği anlatımı kitabında yer vermektedir. Niçin ve neden sorusuna okuyucuyu yöneltir. Bu yüzden yazarın amacı ve ya aktarmak istediği bilgiyi önceden belirler. Bir yola çıkmadan amaç önemlidir (FZ5E24)".

- "Yazarın amacını bilmeden, onun kitabının vermek istediği fikri asla bilemezsin", kesinlikle yanlış bir düşünce; çünkü eğer bir kitap okuyor isek o kitabı kimin yazdiğına bakılmadan okuyorum. Kitapta işlenen konu bence bizi ilgilendirmemelidir(FZ4E19)".

- "Yazar belirli bir ideoloji çerçevesinde kendi fikrini insanları memnun ettirmek için kitap yazarak bu durumu kullanir (FN3K7)".

- "Bizler için amaç değil okuduğun kitapta ne anladığın, amaç kitapta ne bilgi vermek istediğini kendi fikrinle yorumlamaktır (FN2K5)".

Tablo 2' de görüldüğü gibi araştırmaya katılan öğrencilerin ölçeğin üçüncü boyutu olan öğrenme hızı alt boyutuna ilişkin bilimsel epistemolojik inançları $(X=2.53)$ orta düzeyden biraz yüksek çıktığı görülmektedir. Bu durum öğrencilerin "öğrenmenin hemen gerçekleştiğini, basit olduğunu" düşündüklerini ortaya koymaktadır. Öğrencilerle yapılan görüşmelerde "öğrenmenin hızı" boyutunda öğrencilerin tamamının "öğrenmenin birikimli bir süreç olduğu", "kademeli gerçekleştiği" görüşüne sahip oldukları belirlenmiştir. Bu boyutta öğrencilerin belirttiği görüşlerden bazıları aşağıdaki gibidir: 
- "Öğrenme yetisi doğuştan gelir. Bu yeti sayesindeki bilgi kazanımları öğrenmeyi oluşturur. Duyularımız sayesinde aldı̆̆ımız ve belleğimizde oluşan bilgilerin üstüne yenisi eklemekte ve diğer bilgilerle belleğimizde ilişkilendirilerek ögrenme gerçekleşmektedir. Öğrenme aslında bir süreçtir. Hayatımı boyunca yaşadıklarımız, deneyimlerimiz aldı ̆̆ımız bilgilerle ilişkilendirilen uzun bir süreçtir (FN1K1)".

- "Öğrenme bilginin yavaşça üst üste inşa edildiği bir işlemdir. Ĕger böyle olmasayd,, ögrenmeye ilkokulda alfabeden değil, limit ve türevden başlardı (FZ2E14)".

- "Birden hiçbir şeyi ögrenemezsin. Öğrenmeyi inşaat olarak düşünürsek, bilgi de tuğladır. Tuğlalar üst üste konularak inşaat oluşturulur (FZ4E20)".

- "Öğrenme bir anda olmaz. Örneğin ortaokul mezunu bir ögrenciyi direkt üniversiteye alamayız. Çünkü üniversiteden önce ögrenmesi gereken şeyler vardır. Seviyesi kaldırmaz. Öğrencinin belli bir kapasitesi vardır. Öğrenme devaml ama yavaş yavaş olmalıdır (FZ5E23)".

- "Insan ancak adım adım bir şeyleri öğrenir. Birden yüklense, her şeyi bir kerede almaya çalı̧̧sa ne hedefine ulaşır; ne de istediği gibi öğrenme olur. Bir sürü elmayı bir seferde gögüslediğimizi düşünürsek; muhakkak bazıları kollarımızın arasından düşecektir (FZ5E21)".

- Ö̆̆renmek zamanla bilginin üst üste inşa edildiği bir işlemdir. Zaten günümüzde de yapılandırmacı model bu konu üzerinde durmaktadır. Eski bilgilerle yeni bilgilerin sentezidir (FZ5E24)".

Tablo 2' ye bakıldığında araştırmaya katılan öğrencilerin bilginin kesinliği alt boyutuna ilişkin bilimsel epistemolojik inançlarının da $(X=2.75)$ yüksek düzeyde olduğu belirlenmiştir. $\mathrm{Bu}$ durum öğrencilerin bilginin kesin/değiştirilemez inancına kısmen inandıklarını ortaya koymaktadır. Araştırmada bilginin kesinliği boyutunda öğrencilerin yarısı "hiç bir şey kesin değildir", görüşünü savunurken, diğer yarısı "her şeyde bir kesinlik vardır" ve "kesinlik diye bir şey hem vardır, hem de yoktur" görüşünü savunmuştur. "Hiç bir şey kesin değildir",olgusunu savunan öğrenciler bilginin kesinlik içermediğini, sürekli değişebileceğini, bilginin kesinliğinin yanlış olduğunu, zaman geçtikçe doğru dediğimiz bir sürü şeyin yanlış olabileceği yönünde görüş belirtmişlerdir. "Her şeyde bir kesinlik vardır", bu olgusuna ilişkin öğrenciler "sonucuna ulaşılan her şeyde bir kesinlik vardır", gibi görüşler öne sürmüşlerdir. "'Kesinlik diye bir şey hem vardır, hem de yoktur", önermesini savunan öğrenciler ise; kesinlik diye bir şeyin hem doğru hem de yanlış olduğu görüşünü öne sürmüşlerdir. Bu boyutta öğrencilerin belirttiği görüşlerden bazıları aşağıdaki gibidir.

- "Evrendeki her şey bir değişim içindedir. Bu yüzden her an her şey değişebilir. yani hiç bir şey kesin değildir (FN1K1)".

- "Insan inançları doğrultusunda hareket ettiği için hiçbir şeyin kesin olmadığına kanaat getirir. Bazen çok kesin bilgini, bir bilgini kullanman gerektiğinde ya da birisiyle paylaşman gerektiğinde tam manasıyla ifade edemezsin. Insanin korkularl, beklentileri ve duygularını göz önünde bulundurursak, hiçbir şey kesin değildir (FZ4E21)".

- "Kesinlik diye bir şey yoktur. En net bildiğimiz bir şeyin bile zamanı geldiğinde tersi olma durumu söz konusu olabilir veya tersi ispatlanabilir. Bazen \% 100 kesin dediğimiz şeylerin bile öyle olmadığını zamanla anlarız. \% 0,000' lik bir ihtimal daima vardır (FZ5E23)".

- "Günümüz dünyasında teknoloji hızla geliştiği için her şey her an olabilir. Tıp bilimi, sanayi, bilimsel konular her zaman yeniliğe açıktır. Kesin olarak baktı̆̆ımız şeyler yanlışlanabilir. Bu yüzden hiçbir şey kesin değildir (FZ4E20)".

- "Hayatta karşıma çıkan olaylarda kesine yakın tahminlerde bulunabilirim. Fakat içinde bulunduğumuz dini ve ahlaki durumda bazı inançlara inanıyoruz. O inançlar bizim için ispatlanabilir olmasa da onun kesinliğini biliyoruz (FZ2E14)". 
- "İnsanoğlu bir imtihan için yaratıld ve ilahi olan her şey kesindir (FN3E8)".

- "Kesinlik kavramı çok geniş bir yelpazedir. Fiziksel, biyolojik, kimyasal olarak bakıldığında hiçbir şey kesin değilmiş gibi geliyor. Fakat metafizik boyutta bakıldı̆̆ında bir kesinlik görmek mümkün gibi geliyor (FN4E12)".

- "Bir şey varsa o vardır. Matematik, fizik, kimya hakkında işlem varsa, sonuçta kesinlik vardır ama hayat sadece bunlardan ibaret değildir. Bu nedenle kesin bir şey var mı bilmem ama benim şu an ne düşündüğüm bile kesin değil (FZ3K18)".

\section{Bulgular}

Öğrencilerin Kişisel Özelliklerine Göre Epistemolojik İnançlarına İlişkin

Öğretmen adayı öğrencilerin epistemolojik inançlarının cinsiyet ve bölüm değişkenlerine göre farklılaşıp farklılaşmadığına ilişkin yapılan t-testi analizi sonuçları Tablo 3' te verilmiştir.

Tablo 3. Öğrencilerin epistemolojik inançlarına ilişkin t testi sonuçları

\begin{tabular}{lllccccc}
\hline Değişkenler & Düzey & $\mathrm{n}$ & $\bar{X}$ & $\boldsymbol{s s}$. & $\boldsymbol{s} \boldsymbol{d}$. & $\boldsymbol{t}$ & $\boldsymbol{p}$ \\
\hline Cinsiyet & Kadın & 138 & 170,54 & 17,71 & 278 & 1,01 &, 65 \\
& Erkek & 142 & 172,70 & 17,87 & & & \\
\hline \multirow{2}{*}{ Bölüm } & Fen Bilgisi Öğgr. & 205 & 172,24 & 17,77 & 278 & \multirow{2}{*}{, 94} &, 79 \\
& Fizik Öğr. & 75 & 169,99 & 17,87 & & & \\
\hline
\end{tabular}

Tablo 3' te görüldüğü gibi, öğrencilerin bilimsel epistemolojik görüşleri arasında cinsiyet değişkeni açısından anlamlı bir fark $\left[\mathrm{t}_{(278)}=1,01 ; \mathrm{P}>.05\right]$ bulunmamıştır. Aynı şekilde öğrencilerin epistemolojik inançlara ilişkin görüşleri arasında bölüm değişkenine göre de anlamlı bir farklılık $\left[\mathrm{t}_{(278)}=, 94 ; \mathrm{P}>.05\right]$ bulunmamıştır. Buna göre fen bilgisi öğretmenliği öğrencileri ile fizik öğretmenliği öğrencilerinin epistemolojik inançlarının birbirine benzer olduğu söylenebilir.

Öğretmen adayı öğrencilerin epistemolojik inançlarının sınıf değişkenlerine göre farklılaşıp farklılaşmadığına ilişkin yapılan varyans analizi (ANOVA) analizi sonuçları Tablo 4'te verilmiştir.

Tablo 4. Öğretmen adaylarının epistemolojik inançlarına ilişkin betimsel istatistikler

\begin{tabular}{|c|c|c|c|c|c|c|c|c|c|c|}
\hline Bölüm & Sinif & $\mathrm{N}$ & $\bar{X}$ & ss. & Düzey & $\mathrm{KT}$ & $\mathrm{sd}$ & $\mathrm{KO}$ & $\mathrm{F}$ & $\mathrm{P}$ \\
\hline \multirow{5}{*}{ 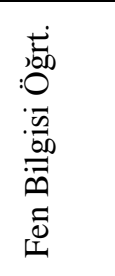 } & 1.sinif & 26 & 170,84 & 18,09 & Gruplar Arası & 1038,25 & 3 & 346,08 & 1,09 &, 35 \\
\hline & 2.sinif & 51 & 170,72 & 14,58 & Gruplar İçi & 63387,55 & 201 & 315,36 & & \\
\hline & 3.sinif & 66 & 170,75 & 18,28 & Toplam & 64425,80 & 204 & & & \\
\hline & 4.sinif & 62 & 175,66 & 19,35 & & & & & & \\
\hline & Toplam & 205 & 172,24 & 17,77 & & & & & & \\
\hline \multirow{5}{*}{ 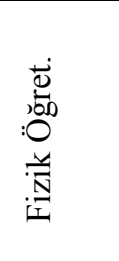 } & $2 . \sin 1 f$ & 19 & 173,15 & 21,93 & Gruplar Arası & 309,568 & 3 & 103,18 &, 31 &, 81 \\
\hline & 3.sinif & 17 & 170,23 & 16,30 & Gruplar İçi & 23341,41 & 71 & 328,75 & & \\
\hline & 4.sinif & 15 & 169,00 & 18,41 & Toplam & 20650,98 & 74 & & & \\
\hline & 5.sinif & 24 & 167,91 & 15,71 & & & & & & \\
\hline & Toplam & 75 & 169,98 & 17,87 & & & & & & \\
\hline
\end{tabular}


Tablo 4'te görüldüğü gibi fen bilgisi bölümü $\left[\mathrm{F}_{(3-201)}=1,09 ; \mathrm{P}>.05\right]$ ve fizik öğretmenliği bölümü $\left[\mathrm{F}_{(3-71)}=, 31 ; \mathrm{P}>.05\right]$ öğretmen adaylarının bilimsel epistemolojik inançları sınıf düzeyine göre anlamlı farklılık göstermemektedir. Buna göre öğretmen adayı öğrencilerin birinci sınıftaki bilimsel epistemolojik inançlarını son sınıfa kadar değiştirmeden sürdürdükleri söylenebilir.

\section{TARTIŞMA VE SONUÇ}

Öğretmen adayı üniversite öğrencilerinin epistemolojik inançlarının belirlenmesinin amaçlandığ 1 bu araştırmada elde edilen nicel bulgular değerlendirildiğinde; öğretmen adaylarının öğrenmenin doğuştanlığına ilişkin görüşlerinin orta düzeyde olduğu belirlenmiştir. Başka bir ifadeyle öğrenciler öğrenmenin doğuştan olduğu görüşüne orta düzeyde katılmışlardır. Bu boyutla ilgili nitel bulgular, nicel bulguları desteklemektedir. Öğretmen adaylarının çoğunluğunun öğrenme yeteneğinin doğuştan olduğunu savundukları belirlenmiştir. Bu durum örneklemde yer alan öğrencilerin çoğunluğunun geleneksel bilim anlayışı içinde olduklarını ortaya koymaktadır.

Schommer'e (1990) göre, gelişmemiş ya da olgunlaşmamış epistemolojik inançlara sahip olan bireyler; öğrenme yeteneğinin doğuştan olduğunu ve sonradan geliştirilemeyeceğini düşünürlerken gelişmiş ya da olgunlaşmış epistemolojik inançlara sahip bireyler öğrenmenin zaman aldığını ve çaba gerektirdiğini düşünürler. Bilimsel epistemolojik inanç düzeyi ile ilişkili olan öğrenme yaklaşımları, öz düzenleme gibi boyutların epistemolojik inanç düzeyini etkilediği ve bu anlamda öğretmen adaylarının sıkıntılarının olduğu sonucu ortaya çıkmıştır. Valanides ve Angeli (2005), üniversite öğrencilerine eleştirel düşünme ilkelerinin öğretilmesinin, öğrencilerin epistemolojik inançları üzerindeki etkisiyle birlikte, bu etkinin öğretimde kullanılan yaklaşımlarla anlamlı düzeyde bir ilişkisinin olup olmadığını araştırmışlardır. Araştırmadan elde edilen bulgulara göre, eleştirel düşünme ilkelerinin öğretilmesi öğrencilerin epistemolojik inançları üzerinde anlamlı düzeyde farklılıklar oluşturmasına rağmen, bu ilkelerin öğretiminde kullanılan öğretim yöntemleri öğrencilerin epistemolojik inançlarının farklılaşmasında anlamlı düzeyde bir etkisi olduğu görülmüștür. Chan ve Elliott (2000), öğretmenlik programında öğrenim gören öğrenciler üzerinde yaptıkları araştırmada gelişmiş epistemolojik inançlara sahip öğrencilerin öğrenmeyle ilgili daha derin yaklaşımlara, gelişmemiş epistemolojik inançlara sahip öğrencilerin ise ezber gibi daha yüzeysel yaklaşımlara yöneldikleri belirlenmiştir.

Araştırmada epistemolojik inançlar ölçeğinin ikinci boyutunda öğretmen adaylarının bilginin basitliği görüşüne orta düzeyde katıldıkları bulgusuna ulaşılmıştır. Schommer'e (1990) göre olgunlaşmış epistemolojik inançlara sahip bireyler bilginin karmaşık olduğunu düşünürler. Bu sonuç ile öğretmen adaylarının bilginin hem karmaşık bir süreç olduğu hem de basit bir süreç olma kararsızlığını yaşadıklarını göstermektedir. Nitel bulgulara baktığımızda ise öğretmen adaylarının bilginin basit olduğu yönünde açıklamalarıyla gelişmemiş/olgunlaşmamış epistemolojik inançlara sahip oldukları ortaya çıkmaktadır.

Araştırmanın epistemolojik inançlar ölçeğinin üçüncü boyutu olan öğrenmenin hızına ilişkin boyutta öğretmen adaylarının öğrenmenin hemen gerçekleştiğini düşündükleri sonucuna ulaşılmıştır. Oysa öğretmen adaylarıyla yapılan nitel görüşmelerde öğrenmenin hızı boyutunda öğretmen adaylarının tamamının "öğrenmenin birikimli bir süreç olduğu", "kademeli gerçekleştiği" görüşünü ortaya koyarak nicel bulgulardan farklı bir sonuç belirttikleri sonucuna ulaşılmıştır. Bu durum, sosyal gerçekliği açıklamada nicel verilerin yetersiz kalabileceğini ve yanıltıcı olabileceğini, sosyal araştırmalarda nicel verilerin nitel verilerle desteklenmesinin ne denli önemli olduğunu ortaya koyması açısından önemlidir. $\mathrm{Bu}$ da sosyal çalışmalarda karma araştırmaların önemini ve sağladığı avantajları ortaya koymaktadır. Braten ve Stromso (2005) epistemolojik inançları (öğrenme hızı, bilginin 
kesinliği, bilgi ediniminin kontrolü, bilgi oluşturma ve dönüştürme), zekânın örtük teorileri ve öz-düzenleyici öğrenme (öz-yeterlilik, öğrenme amacına odaklılık ve ilgi) arasındaki ilişkileri, işletme ve eğitim fakültelerinin 1. sınıflarında öğrenim gören öğrencilerden oluşan bir çalışma grubuyla incelemişlerdir. Araştırmadan elde edilen bulgular, bağımlı değişkenler olarak epistemolojik inançların akademik bağlamdan etkilenmediğini, ancak zekânın örtük teorileri için böyle bir etkinin söz konusu olduğu yönündedir. Buna göre, öğretmen adayları zekânın sabit bir görünüme sahip olmadığına ve geliştirilebileceğine işletme alanında öğrenim gören öğrencilere kıyasla anlamlı düzeyde daha fazla inanmaktadırlar. Bununla birlikte, öğretmen adaylarının zekânın sabit bir nitelik olduğuna ve öğrenmenin ya hızlı bir biçimde gerçekleşeceğine ya da hiçbir şekilde gerçekleşmeyeceğine inandıkları oranda, düşük öz yeterliliğe sahip oldukları ortaya çıkmıştır. İşletme alanında öğrenim gören öğrencilerin ise bilginin kesinliğine, bilgi oluşturma ve dönüştürmenin basitliğine inandıkları ölçüde düşük öz yeterliğe sahip olduklarına ilişkin bulgular, araştırmadan elde edilen önemli bulgular arasında yer almaktadırlar.

Araştırmada epistemolojik inançlar ölçeğinin dördüncü boyutu olan bilginin kesinliğine ilişkin boyutta öğretmen adaylarının görüşlerinin orta düzeyde olduğu belirlenmiştir. Görüşme sonuçlarına göre ise öğrencilerin çoğunluğunun bilginin kesinliğine inandıkları sonucu ortaya çıkmıştır. Trautwein ve Lüdtke (2007), üniversite öğrencilerinin epistemolojik inançlarıyla okul başarılarını, öğrenimini gördükleri alan değişkeni kapsamında (sosyal, bilimler, tıp, doğa bilimleri, mühendislik, hukuk, sanat alanları ve işletme) ve boylamsal bir yaklaşımla incelemişlerdir. Araştırmada, cinsiyet, yaş, sosyoekonomik düzey, bilişsel beceri ve ailenin sahip olduğu kitap sayısını ifade eden kültürel sermaye değişkenleri de dikkate alınırken, epistemolojik inanç boyutlarından bilginin kesinliği boyutuna odaklanılmıştır. Araştırmadan elde edilen bulgulara göre, öğrencilerin cinsiyetleri, kültürel sermayeleri ve bilişsel becerileri, bilginin kesinliğine ilişkin inançlarını negatif bir biçimde yordarken; bilginin kesinliğine ilişkin inançları ise okul başarılarını negatif bir biçimde öngörmektedir.

Genel olarak elde edilen bulgular değerlendirildiğinde öğrencilerin öğrenmenin hızına ilişkin epistemolojik inançlarının diğer alanlara göre daha gelişkin olduğu sonucuna ulaşılmıştır. Ayrıca bilginin kesinliğine ilişkin epistemolojik inançlarının gelişkin ve olması gereken düzeye yakın olduğu söylenebilir.

$\mathrm{Bu}$ araştırmada öğretmen adaylarının epistemolojik inançlarının, cinsiyet değiş̧kenine göre değiş̧mediği belirlenmiştir. Meral ve Çolak (2009) ile Deryakulu ve Büyüköztürk'ün (2005) araştırmalarında ise, kız öğrencilerin epistemolojik inançlarının erkeklere göre daha gelişmiş olduğu belirlenmiştir. Öngen (2003), eğitim fakültesi öğrencileri üzerinde yaptığ araştırmada, k1z öğrencilerin öğrenmenin yeteneğe bağlı olduğuna erkek öğrencilere göre daha az inanma eğiliminde olduklarını ve öğrenmenin çabaya bağlı olduğuna inanç boyutunun problem çözme stratejilerini yordamada önemli olduğunu ortaya koymuştur. Belenky ve arkadaşlarının (1986) araştırmasında da erkeklerin ayrı bilme (kişisellikten uzak bir yaklaşım) yollarına sahip olmalarına karşılık, kadınların ilişkisel bilme (bilmeye empatik yaklaşım) yollarına sahip oldukları ortaya konmuştur. Baxter-Magolda (1992), erkek ve kız öğrencilerin bilme yollarına ilişkin olarak farklı yönelimler elde etmiş ve kız öğrencilerin erkek öğrencilere kıyasla bilmenin bağlamsal yollarını kullanmaya daha fazla eğilimli olduklar sonucuna ulaşmıştır.

Araştırmada öğrencilerin epistemolojik inançlarının öğrenim gördükleri bölümlere göre farklılaşmadığ 1 ortaya çıkmıştır. Ancak araştırmaya dahil edilen her iki bölüm de fen alanıyla ilgilidir. Deryakulu ve Büyüköztürk (2005), sınıf öğretmenliği ve sosyal bilgiler öğretmenliği öğrencilerinin, bilgisayar ve öğretim teknolojileri eğitimi öğrencilerine kıyasla daha olgunlaşmış epistemolojik inançlara sahip olduklarını belirlemişlerdir. Hofer (2000), 
yaptığı araştırmada öğrencilerin psikoloji ve fen bilim alanlarına ilişkin epistemolojik inançlarının farklılaştığını belirlemiştir. Buna göre öğrencilerin fen bilimleri alanında, psikoloji alanına göre bilginin daha kesin ve değişmez olduğuna inandıkları ortaya çıkmıştır. Ayrıca, öğrencilerin psikoloji alanında bilme sürecinin kişisel yaşantılara daha fazla dayandığına; fen bilimlerinde ise otorite ve uzmanların bilgi kaynağ 1 olarak daha fazla ön planda olduğuna ve fen bilimlerinde gerçekliğin psikoloji alanında olduğundan daha fazla ulaşılabilir bir olgu olduğuna inandıkları ortaya konmuştur.

$\mathrm{Bu}$ çalışmanın en önemli sonucu; öğretmen adayı öğrencilerin epistemolojik inançları arasında sınıf düzeylerine göre anlamlı fark olmadığıdır. Buna göre birinci sınıftaki epistemolojik inançları son sınıfa kadarki öğrenimleri süresince önemli şekilde değişmemektedir. Başka bir ifadeyle üniversite eğitimi, öğrencilerin bilginin doğasına ilişkin inançları üzerinde bir değişim yaratmamaktadır. Oysaki üniversite eğitimi boyunca eğitimin ilk yılları ile son yılları arası öğrencilerin bilimsel epistemolojik inançlarında olgunlaşma/gelişme beklenir (Hofer (2004a). Literatüre bakıldığında pek çok araştırmacının (Schommer-Aikins, Duell ve Hutter, 2005; Schommer-Aikins, 1990, 1994; Schommer-Aikins ve Easter, 2006; Chan ve Elliott, 2002, 2004; Braten ve Stromso, 2005, 2006; Perry, 1970; King ve Kitchener, 1994;, Baxter-Magolda,1992; Belenky ve arkadaşları, 1986) bireylerin epistemolojik inançlarının, eğitim düzeyi vb. özelliklerine göre ardışık bir gelişim gösterdiğini öne sürdükleri görülmektedir. Araştırmada ulaşılan bu sonuç bazı araştırma sonuçları ile örtüşürken (Öngen, 2003; Meral ve Çolak, 2009; Deryakulu ve Büyüköztürk, 2005), bazı araştırma sonuçlarıyla da çelişmektedir (Hofer, 2004; Chan ve Elliott, 2000; Perry, 1970).

Bu konuda Meral ve Çolak (2009), yaptıkları araştırmada ilginç bir bulgu olarak sınıf tekrarı yapan öğrencilerin diğerlerine göre daha güçlü yapılandırmacı inanca sahip oldukları sonucuna ulaşmışlardır. Hofer (2004a), fen bilimleri alanında öğrenim gören üniversite öğrencileri üzerinde yaptığı araştırmada öğrencilerin epistemolojik varsayımlarının dönem içerisinde gelişim gösterdiğini ve öğretim elemanlarının bu gelişimi değişik yollarla etkilediklerini ortaya koymuştur. Öğrencilerin üniversiteye belli bir bilgi birikimi ile geldikleri, dolayısıyla bir alana yönelik belirli epistemolojik varsayımları bulunduğunu ve bu varsayımların geçerliliğinin öğrencinin başarısında önemli bir faktör olduğu ve öğretim elemanlarının bu varsayımları etkileyebilmelerinden dolayı önemli sorumlulukları olduğu belirtilmektedir (Hofer, 2004a).

Yurtdışında yapılan araştırmaların çoğu üniversite eğitiminin öğrencilerin epistemolojik inançlarının gelişimi üzerinde etkili olduğunu ortaya koyarken; bu araştırma ile birlikte Türkiye'de yapılan araştırmalar (Öngen, 2003; Meral ve Çolak, 2009; Deryakulu ve Büyüköztürk, 2005), üniversite eğitiminin öğrencilerin bilginin ve bilmenin doğasına ilişkin geleneksel bilim anlayışına dayalı epistemolojik inançları üzerinde bir değişim yaratmadığını ortaya koymaktadır. Bu sonuçlar, Schommer(1990, 1998, 2004) 'in ortaya koyduğu ilkelerle değerlendirildiğinde; yapılandırmacı eğitimin benimsendiği günümüzde üniversitelerimizde halen öğrencilerin sahip olduğu geleneksel bilim anlayışına dayalı epistemolojik inançları üzerinde etkili olamayan geleneksel eğitimin güçlü izlerini gözler önüne sermektedir. Özellikle öğretmenlerin aldığı eğitimin, öğrencilerin epistemolojik inançlarını etkilediği (Brownlee, 2001), araştırmaya dayalı ve uygulamalı eğitimin öğrencilerin epistemolojik inançlarının gelişimine katkıda bulunduğu (Kızılgüneş ve diğ., 2009) gerçeği göz önüne alındığında üniversitelerde tüm alanlarda olduğu gibi öğretmen yetiştiren programlarda inşaci/ yapılandırmacı öğrenmeye dayalı uygulama ağırlıklı eğitim sisteminin yerleşmesi için üniversite eğitiminin daha güçlü şekilde tartışılmasının gereği açıktır. Üniversite eğitiminin bilimsel sorgulama ve tartışmayı daha fazla merkeze alan bir yapıya kavuşturulması için sorgulamanın yoğun olarak yapıldığı felsefe gibi derslerin programlarda yer alması da önerilebilir. 
Epistemolojik inançların hem genel (Schommer, 1990, 1994; Schommer vd., 2000) hem de alan odaklı (Buehl, 2003) bakış açılarıyla incelendiği araştırmalardan elde edilen bulgular dikkate alındığında, öğretme-öğrenme süreçlerinin planlanması ve gerçekleştirilmesinde epistemolojik inançlar konusunun önemli bir konumda yer aldığ1 görülmektedir. Bu noktada ders veren öğretim üyelerinin gerek öğrenme- öğretme süreçleri gerek değerlendirme yöntemlerinde epistemolojik inançlarının gelişimine katkı sunacak şekilde süreci izleyebilir.

$\mathrm{Bu}$ araştırma eğitim fakültesinin belli bölümleri üzerinde yürütüldüğünden edebiyat ve sosyal alanlar bölümleri ile fen ve matematik alanları eğitiminin diğer bölümleri ile yapılarak sonuçlar değerlendirilebilir.

Araştırmacılara, ileride yapılacak çalışmalarda bilimsel epistemolojik inanç düzeyi ile ilişkili olduğu düşünülen öğrenme stratejisi, öğrenme yaklaşımları, öz düzenleme gibi boyutların epistemolojik inanç düzeyi ile ilişkisini inceleyen çalışmalara yer verilmesi ve eğitim programlarının bireylerin bilimsel epistemolojik inançları üzerindeki etkisinin belirlenmesine yönelik olarak deneysel çalışmaların yapılması önerilmektedir.

\section{KAYNAKLAR}

Baxter-Magolda, M. B. (1992). Knowing and reasoning in college: gender-related patterns in students' intellectual development, San Francisco: Jossey Bass.

Belenky, M. F., Clinchy, B. M., Goldberger, N. R. ve Tarule, J. M. (1986). Women's ways of knowing: The development of self, voice and mind. New York; Basic Books.

Bernardo, A. B. I. (2008). Exploring epistemological beliefs of bilingual Filipino preservice teachers. The Journal of Psychology, 142 (2), 193-208.

Braten, I. ve Stromso, H. I. (2005). The relationship between epistemological beliefs, 1mplicit theories of intelligence, and self-regulated learning among Norwegian postsecondary students. British Journal of Educational Psychology, 75, 539-565.

Braten, I. ve Stromso, H. I. (2006). Epistemological beliefs, interest, and gender as predictors of internet-based learning activities, Computers in Human Behavior, 22, 1027-1042.

Brownlee, J. (2001). Beliefs about knowing in pre-service teacher education students. Ed: L. Richardson \& J. Lidstone (Eds), Flexible Learning for a Flexible Society, 75-82.

Buehl, M. ve Alexander, P. A. (2001). Beliefs about academic knowledge, Journal of Educational Psychology Review, 13 (4), 353-382.

Buehl, M. (2003). At the crossroads of epistemology and motivation: Modeling the relations between students' domain-specific epistemological beliefs, achievement motivation, and task performance. (Yayınlanmamış doktora tezi). Maryland Üniversitesi. Amerika.

Cavallo, A. M. L., Rozman, M., Blickenstaff, J. ve Walker, N. (2003). Students' learning approaches, reasoning abilities, motivational goals, and epistemological beliefs in differing college science courses, Journal of College Science Teaching, 33, 18-23.

Cano, F. (2005). Epistemological beliefs and approaches to learning: Their change through secondary school and their influence on academic performance, British Journal of Educational Psychology, 75, 203-221.

Chan, K. W. ve Elliott., R. G. (2002). Exploratory study of Hong Kong teacher education students' epistemological beliefs: Cultural perspectives and implications on belief research. Contemporary Educational Psychology, 27, 392-414. 
Chan, K. (2003). Hong Kong teacher education students' epistemological beliefs and approaches to learning. Research in Education, 69, 36-50.

Chan, K. W. ve Elliott, R. G. (2004). Epistemological beliefs across cultures: Critique and analysis of beliefs structure studies. Educational Psychology, 24(2), 123-142.

Creswell, J. W., Clark, V. L. P., Gutmann, M. L. ve Hanson, W. E. (2003). Handbook of mixed methods in social \& behavioral research. A. Tashakkori ve C. Teddlie (Ed.). Advanced mixed methods research designs (s. 223-227). Thousand Oaks, London: Sage Publications.

Demirel, Ö. (2004). Ĕgitimde program geliştirme. Ankara: Pegem A Yayıncılık.

Deryakulu, D. ve Büyüköztürk, Ş. (2002). Epistemolojik inanç ölçeğinin geçerlik ve güvenirlik çalışması, Eğitim Araştırmaları, 8, 111-125.

Deryakulu, D. (2004) Üniversite öğrencilerinin öğrenme ve ders çalışma stratejileri ile epistemolojik inançları arasındaki ilişki, Kuram ve Uygulamada Eğitim Yönetimi, 38, 230-249.

Deryakulu, D. ve Büyüköztürk, Ş. (2005). Epistemolojik inanç ölçeğinin faktör yapısının yeniden incelenmesi: Cinsiyet ve öğrenim görülen program türüne göre epistemolojik inançların karşılaştırılması. Eğitim Araştırmaları, 18, 57-70.

Duell, O. K. ve Schommer-Aikins, M. (2001). Measures of people's beliefs about knowledge and learning, Educational Psychology Review,13(4), 419-449.

Hofer, B. K. ve Pintrich, P. R. (1997). The development of epistemological theories: Beliefs about knowledge and knowing and their relation to learning, Review of Educational Research, 67(1), 88-140.

Hofer, B. K. (2000). Dimensionality and disciplinary differences in personal epistemology, Contemporary Educational Psychology, 25, 378-405.

Hofer, B. K. (2004a). Exploring the dimensions of personal epistemology in differing classroom contexts: Student interpretations during the first year of college, Contemporary Educational Psychology, 29, 129-163.

Kizilgünes, B., Tekkaya, C. ve Sungur, S. (2009). Modeling the relations among students' epistemological beliefs, motivation, learning approach, and achievement. The Journal of Educational Research, 102(4), 243-255.

King, P. M. ve Kitchener, K. S. (1994). Developing reflective judgment: Understanding and promoting intellectual growth and critical thinking in adolescents and adults. San Francisco: Jossey-Bass.

Llyod, G. (2003). Mathematics teachers' beliefs and experiences with innovative curriculum materials: The Role of Curriculum in Teacher Development, (Ed: G. C. Leder., E. Pehkonen ve G. Törner) Beliefs: A Hidden Variable in Mathematics Education? (ss. 149-159), New York: Kluwer Academic Publishers.

Mason, L. ve Boscolo, P. (2004). Role of epistemological understanding and interest in interprating a controversy and in Topic-Specific Belief Change, Contemporary Educational Psychology, 29, 103-128.

Meral, M. ve Çolak, E. (2009). Öğretmen adaylarının bilimsel epistemolojik inançlarının incelenmesi. On dokuz Mayıs Üniversitesi Ĕ̆itim Fakültesi Dergisi, 27, 129-146. 
Öngen, D. (2003). Epistemolojik inançlar ile problem çözme stratejileri arasındaki ilişkiler: Eğitim fakülteleri öğrencileri üzerinde bir çalışma, Eğitim Araştırmaları, 13,155-162.

Perry, W. G. (1970). Forms of intellectual development and ethical development in the college years: A scheme. New York: Holt, Rinehart \& Winston.

Schommer, M. (1990). Effects of beliefs about the nature of knowledge on comprehension, Journal of Educational Psychology, 82, 498-504.

Schommer, M. (1994). Synthesizing epistemological belief research: Tentative understandings and provocative confusions, Educational Psychology Review, (4), 293319.

Schommer-Aikins, M., Brookhart, S., Hutter, R. ve Mau, W. C. (2000). Understanding middle students' beliefs about knowledge and learning using a multidimensional paradigm, The Journal of Educational Research, 94 (4), 20-127.

Schommer-Aikins, M. (2004). Explaining the epistemological belief system: Introducing the embedded systemic model and coordinated research approach. Educational Psychologist, 39(1), 19-29.

Schommer-Aikins, M. ve Easter, M. (2006). Ways of knowing and epistemological beliefs: Combined effect on academic performance, Educational Psychology, 26(3), 411-423.

Topçu, M.S. (2011). Turkish elementary student teachers' epistemological beliefs and moral reasoning. European Journal of Teacher Education, 34(1), 99-125.

Trautwein, U. ve Lüdtke, O. (2007). Epistemological beliefs, school achievement, and college major: A large-scale longitudinal study on the 1mpact of certainty beliefs, Contemporary Educational Psychology, 32, 348-366.

Valanides, N. ve Angeli, C. (2005). Effects of instruction on changes in epistemological beliefs. Contemporary Educational Psychology, 30, 314-330.

Yılmaz-Tüzün, Ö. ve Topcu, M. S. (2008). Relationships among preservice science Teachers' epistemological beliefs, epistemological world views. International Journal of Science Education, 30(1), 65-85. 